Article

\title{
The In Vitro Activity of Essential Oils against Helicobacter Pylori Growth and Urease Activity
}

\author{
Izabela Korona-Glowniak $^{1, *\left(\mathbb{C}, \text { Anna Glowniak-Lipa }{ }^{1}, \text { Agnieszka Ludwiczuk }^{2}{ }^{\circledR} \text {, Tomasz Baj }\right.}{ }^{3}$ \\ and Anna Malm ${ }^{1}$ (D) \\ 1 Department of Pharmaceutical Microbiology, Medical University in Lublin, 1 Chodzki Str., \\ 20-093 Lublin, Poland; glowniak.lipa@gmail.com (A.G.-L.); anna.malm@umlub.pl (A.M.) \\ 2 Independent Laboratory of Natural Products Chemistry, Department of Pharmacognosy, Medical University \\ in Lublin, 1 Chodzki Str., 20-093 Lublin, Poland; aludwiczuk@pharmacognosy.org \\ 3 Department of Pharmacognosy, Medical University in Lublin, 1 Chodzki Str., 20-093 Lublin, Poland; \\ tbaj@pharmacognosy.org \\ * Correspondence: iza.glowniak@umlub.pl; Tel.: +48-81-448-7105
}

Academic Editor: Luca Forti

Received: 24 December 2019; Accepted: 28 January 2020; Published: 29 January 2020

\begin{abstract}
The anti-H. pylori properties of 26 different commercial essential oils were examined in vitro by MIC (minimal inhibitory concentration) determination for the reference strain H. pylori ATCC 43504. We selected 9 essential oils with different anti-Helicobacter activities and established their phytochemical composition and urease inhibition activities. Phytochemical analysis of the selected essential oils by GC-MS method and antioxidant activity were performed. The phenol red method was used to screen the effect of essential oils on urease activity expressed as $\mathrm{IC}_{50}$ (the half of maximal inhibitory concentration). The most active essential oils, with MIC $=15.6 \mathrm{mg} / \mathrm{L}$, were thyme, lemongrass, cedarwood and lemon balm oils; $\mathrm{MIC}=31.3 \mathrm{mg} / \mathrm{L}$-oregano oil; $\mathrm{MIC}=62.5 \mathrm{mg} / \mathrm{L}$-tea tree oil; MIC $=125 \mathrm{mg} / \mathrm{L} —$ pine needle, lemon and silver fir oils with bactericidal effect. Urease activity was inhibited by these oils with $\mathrm{IC}_{50}$ ranged from 5.3 to $>1049.9 \mathrm{mg} / \mathrm{L}$. The most active was cedarwood oil $\left(\mathrm{IC}_{50}=5.3 \mathrm{mg} / \mathrm{L}\right)$, inhibiting urease at sub-MIC concentrations $(\mathrm{MIC}=15.6 \mathrm{mg} / \mathrm{L})$. The statistical principal component analysis allowed for the division of the oils into three phytochemical groups differing in their anti-H. pylori activity. To summarize, the activity in vitro of the five essential oils silver fir, pine needle, tea tree, lemongrass, and cedarwood oils against $H$. pylori was found in this paper for the first time. The most active against clinical strains of H. pylori were cedar wood and oregano oils. Moreover, cedarwood oil inhibited the urease activity at subinhibitory concentrations. This essential oil can be regarded as a useful component of the plant preparations supporting the eradication H. pylori therapy.
\end{abstract}

Keywords: essential oils; chemical analysis; Helicobacter pylori; antibacterial activity

\section{Introduction}

Helicobacter pylori is an etiological factor of the most frequent and persistent bacterial infection worldwide, which affects nearly half of the world's population. H. pylori is recognized as the major etiological agent of including peptic ulcer disease, gastritis, gastric cancer and functional dyspepsia [1]. Moreover, extra-digestive disorders (idiopathic thrombocytopenic purpura, vitamin B12 deficiency and unexplained iron deficiency anemia) were included as indications for eradication of H. pylori [2]. In recent years, due to increasing antimicrobial resistance of $H$. pylori, treatment of this pathogen has remained a challenge for physicians. Currently, the first-line treatments for H. pylori infections are based 
on the combinations of a proton pump inhibitor and two antibiotics: amoxicillin and clarithromycin or metronidazole (triple therapy). As an alternative, levofloxacin can replace clarithromycin in first-line therapy, with higher cure rates [3]. Moreover, an alternative empiric strategy is mandatory when local clarithromycin resistance is higher than $20 \%$ [2]. When the triple scheme fails, a quadruple therapy containing bismuth (bismuth salts, tetracycline and metronidazole plus PPI) or non-bismuth-based quadruple therapy (i.e., levofloxacin, nitazoxanide and doxycycline plus PPI) must be recommended [2]. Treatment is justified only for symptomatic patients. Therefore, asymptomatic carriers constitute a reservoir of $H$. pylori strains in population, including antibiotic resistant strains which can easily spread. People with asymptomatic infection would benefit from a nutritional line aimed at sustaining a low level of H. pylori density in gastric mucosa preventing from development of severe gastritis and an increased incidence of peptic ulcer. Urease is key enzyme which enables H. pylori survival and colonization by initiating the hydrolysis of urea generating ammonia to neutralize stomach acid in order to create a suitable $\mathrm{pH}$ environment. Hence, urease is considered to be a critical target in the research and exploitation of antibacterial agents [4].

Therapeutic alternatives beyond antibiotics have been investigated in recent years, including vaccines, probiotics, photodynamic inactivation, phage therapy and phytomedicine. Several studies have been performed in the aspect of searching for plants and plant extracts/constituents as anti-H. pylori activity and gastroprotective action [5,6]. Moreover, components of natural origin have been extensively investigated as potential effective urease inhibitors for the treatment of $H$. pylori infection. Essential oils (EOs) have been shown to possess antibacterial, antifungal, antiviral, insecticidal and antioxidant properties [7]. Few articles have described the effects of specific essential oils on H. pylori growth and viability [8-10]. There is scant data on essential oils' in vivo activity. In the study by Ohno et al. [11] the authors reported that the density of H. pylori in the stomach of mice treated with lemongrass was significantly reduced compared with untreated mice. In another study, by Hartmani et. al. [12], the anti-H. pylori activity of 2:1 mixture of Satureja hortensis and Origanum vulgare subsp. hirtum essential oils was investigated. In the in vivo experiments, the mixture successfully eradicated this pathogen in $70 \%$ of the mice.

The aim of this work was to identify EOs with strong antimicrobial activity against $H$. pylori growth. We examined the anti-H. pylori properties of 26 different commercial EOs in vitro. We selected 9 EOs with different anti-Helicobacter activities and established their phytochemical composition and urease inhibition activities.

\section{Results}

\subsection{Anti-H. Pylori Activity of Essential Oils}

The results of antibacterial activity of 26 commercial EOs against reference strain of H. pylori ATCC 43504 are shown in Table 1.

Based on MBC/MIC ratio < 4, it was considered that most of the tested EOs were bactericidal. Thymol, menthol and bisabolol were used as reference compounds showing strong anti-Helicobacter activity. For the further analysis nine of the EOs with different MIC values were chosen: silver fir (SF), pine needle (PI), tea tree (MA), lemongrass (LG), lemon (LE), lemon balm (ME), thyme (TY), oregano $(\mathrm{OR})$ and cedarwood (CE) oils.

\subsection{Analysis of Essential Oils}

The volatile components detected in nine examined EOs are listed in Table 2 in order of their elution from an ZB-5MS column. Chromatographic analysis indicated considerable variability in chemical composition of these EOs. The structures of the most characteristic terpenoids found in the examined EOs are presented on Figure 1. 
Table 1. Activity of 26 commercial essential oils against H. pylori ATCC 43504.

\begin{tabular}{|c|c|c|c|c|c|}
\hline $\begin{array}{l}\text { Essential } \\
\text { Oil Name }\end{array}$ & Plant Name, Family & Supplier & MIC (mg/L) & MBC (mg/L) & MBC/MIC Ratio \\
\hline Thyme & Thymus vulgaris L. Lamiaceae & Avicenna-Oil & 15.6 & 15.6 & 1 \\
\hline Lemongrass & Cymbopogon schoenanthus (L.) Spreng, Poaceae & Avicenna-Oil & 15.6 & 15.6 & 1 \\
\hline Ylang-Ylang & $\begin{array}{l}\text { Related to Cananga odorata Lam. Hook et } \\
\text { Thomson, Annonaceae }\end{array}$ & Avicenna-Oil & 15.6 & 62.5 & 1 \\
\hline Cedarwood & Juniperus virginiana L., Cupressaceae & Bamer & 15.6 & 62.5 & 4 \\
\hline Lemon balm no. 2 & Melissa spp, Lamiaceae & Kej & 15.6 & 62.5 & 4 \\
\hline Basil & Ocimum basilicum L., Lamiaceae & Mogo & 15.6 & 250 & 16 \\
\hline Niaouli & Melaleuca viridiflora Gaertn, Myrtaceae & Bamer & 31.3 & 31.3 & 1 \\
\hline Oregano & Origanum vulgare L. Lamiaceae & Bamer & 31.3 & 31.3 & 1 \\
\hline Clove & Syzyoium aromaticum L., Myrtaceae & Bamer & 31.3 & 31.3 & 1 \\
\hline Lemon balm no. 1 & Melissa spp, Lamiaceae & Avicenna-Oil & 31.3 & 62.5 & 2 \\
\hline Sandalwood & Santalum album L., Santalaceae & Bamer & 31.3 & 62.5 & 1 \\
\hline Petitgrain & Citrus aurantium L. Rutaceae & Bamer & 31.3 & 62.5 & 2 \\
\hline Kajeput & Melaleuca leucadendra L., Myrtaceae & Bamer & 31.3 & 125 & 4 \\
\hline Tea tree & Melaleuca alternifolia Maiden et Betche, Myrtaceae & Avicenna-Oil & 62.5 & 62.5 & 1 \\
\hline Rosemary & Rosmarinus officinalis Lindl., Lamiaceae & Avicenna-Oil & 62.5 & 62.5 & 1 \\
\hline Geranium & $\begin{array}{l}\text { Pelargonium odorantissimum (L.) L'Hér, } \\
\text { Geraniaceae }\end{array}$ & Avicenna-Oil & 62.5 & 62.5 & 1 \\
\hline Sage & Salvia hispanica L., Lamiaceae & Avicenna-Oil & 62.5 & 62.5 & 2 \\
\hline Lavender & Lavandula angustifolia Mill., Lamiaceae & Bamer & 62.5 & 125 & 2 \\
\hline Marjoram & Origanum majorana L., Lamiaceae & Dr.Beta & 62.5 & 250 & 4 \\
\hline Peppermint & Mentha piperita L., Lamiaceae & Ejta & 62.5 & 500 & 8 \\
\hline Hyssop & Hyssopus spp. L., Lamiaceae & Vera & 62.5 & 500 & 8 \\
\hline Eucalyptus & Eucalyptus globulus Labill., Myrtaceae & Kej & 62.5 & 500 & 8 \\
\hline Camphor & Cinnamomum camphora Ness et Eberm. Lauraceae & Bamer & 125 & 125 & 1 \\
\hline Pine needle & Pinus silvestris L., Pinaceae & Kej & 125 & 125 & 1 \\
\hline Lemon & Citrus limon (L.) Osbeck, Rutaceae & Avicenna-Oil & 125 & 250 & 2 \\
\hline Silver fir & Abies alba Mill, Pinaceae & Avicenna-Oil & 125 & 250 & 2 \\
\hline Thymol & Reference & Sigma & 7.8 & 31.3 & 4 \\
\hline Menthol & Reference & Sigma & 15.6 & 31.3 & 2 \\
\hline Bisabolol & Reference & Sigma & 31.3 & 31.3 & 1 \\
\hline
\end{tabular}

Table 2. Chemical composition of the analyzed essential oils.

\begin{tabular}{|c|c|c|c|c|c|c|c|c|c|c|c|}
\hline No. & Compounds & $\mathbf{R I}^{\mathbf{a}}$ & \multicolumn{9}{|c|}{ Chemically Analyzed Essential Oils ${ }^{b}$} \\
\hline 1 & Tricyclene & 922 & & & 0.4 & & & & & & \\
\hline 3 & $\alpha$-Pinene & 936 & 31.1 & 2.8 & 15.5 & 1.4 & 0.1 & & & 2.3 & 2.2 \\
\hline 4 & Camphene & 950 & 1.3 & 0.1 & 4.0 & 0.7 & 0.6 & & & & 0.2 \\
\hline 5 & Sabinene & 973 & & 2.3 & 0.2 & & & & & 0.3 & \\
\hline 7 & Myrcene & 988 & 1.7 & 1.9 & 0.4 & 1.6 & & & & 0.7 & 1.7 \\
\hline 8 & $\Delta^{3}$-Carene & 1009 & 15.0 & & 5.1 & & & & & 0.5 & \\
\hline 9 & $\alpha$-Terpinene & 1017 & 0.1 & 0.1 & & 2.3 & & & & 9.8 & 1.1 \\
\hline 10 & p-Cymene & 1026 & 1.2 & 1.7 & 0.6 & 22.5 & & & & 3.1 & 14.6 \\
\hline 11 & Limonene & 1030 & 12.1 & 58.1 & 9.1 & 0.8 & 0.2 & & 4.4 & 1.0 & 1.1 \\
\hline 12 & 1,8-Cineole & 1034 & & & & 0.4 & & & & 4.1 & 0.8 \\
\hline 17 & Linalool & 1101 & & 0.2 & & 5.5 & 1.0 & & 0.8 & & 2.6 \\
\hline 18 & (Z)-Limonene oxide & 1135 & & 0.1 & & & & & & & \\
\hline 19 & (E)-Limonene oxide & 1139 & & 0.1 & & & & & & & \\
\hline 20 & Isopinocarveol & 1146 & 0.1 & & & & & & & & \\
\hline 21 & Citronellal & 1152 & & & & & 0.3 & & 31.2 & & \\
\hline 22 & (Z)- $\alpha$-Dihydroterpineol & 1154 & 0.2 & & & & & & 0.4 & & \\
\hline 23 & Isopulegol & 1163 & & & & & & & & & \\
\hline 24 & Borneol & 1178 & & & 0.6 & 1.0 & & & & & 0.5 \\
\hline 25 & Terpinen-4-ol & 1187 & & & & 0.6 & & & & 39.6 & 0.2 \\
\hline 26 & $\alpha$-Terpineol & 1199 & 0.5 & 0.1 & 1.0 & 1.4 & 0.1 & & & 3.3 & 0.4 \\
\hline 27 & Fenchyl acetate & 1219 & & & 0.2 & & & & & & \\
\hline
\end{tabular}


Table 2. Cont.

\begin{tabular}{|c|c|c|c|c|c|c|c|c|c|c|c|}
\hline \multirow{2}{*}{ No. } & \multirow{2}{*}{ Compounds } & \multirow{2}{*}{$\mathbf{R I}^{\mathbf{a}}$} & \multicolumn{9}{|c|}{ Chemically Analyzed Essential Oils ${ }^{b}$} \\
\hline & & & PI & LE & SF & $T Y$ & LG & $\mathrm{CE}$ & ME & MA & OR \\
\hline 35 & Isobornyl acetate & 1289 & 0.1 & & 1.9 & & & & & & \\
\hline 36 & Thymol & 1301 & & & & 45.4 & & & & & 0.5 \\
\hline 37 & Carvacrol & 1310 & & & & 3.8 & & & & & 67.7 \\
\hline 38 & Cytronellyl acetate & 1346 & & & & & & & 5.4 & & \\
\hline 39 & $m$-Eugenol & 1355 & & & & & & & 1.1 & & \\
\hline 40 & Naryl acetate & 1355 & & 0.5 & & & & & & & \\
\hline 41 & $\alpha$-Longipinene & 1356 & 0.1 & & & & & & & & \\
\hline 42 & Geranyl acetate & 1374 & & 0.4 & & & 5.6 & & 4.2 & & \\
\hline 43 & Cedr-9-en & 1392 & & & & & & 0.3 & & & \\
\hline 44 & $\beta$-Elemene & 1393 & & & & & 0.3 & & 2.2 & & \\
\hline 45 & $\begin{array}{c}204[\mathrm{M}]^{+}, 119(100) \\
93(82)\end{array}$ & 1396 & & & & & & 1.4 & & & \\
\hline 46 & 7-epi- $\alpha$-Cedrene & 1405 & & & & & & 0.2 & & & \\
\hline 47 & Longifolene & 1418 & 0.8 & & & 0.1 & & & & & \\
\hline 48 & (E)- $\beta$-Caryophyllene & 1426 & 4.2 & 0.4 & 0.7 & 2.6 & 2.5 & & & 0.3 & 2.9 \\
\hline 49 & $\alpha$-Cedrene & 1428 & & & & & & 22.9 & & & \\
\hline 50 & $(E)$ - $\beta$-Farnesene & 1435 & & 0.1 & & & & & & & \\
\hline 51 & $\beta$-Cedrene & 1437 & & & & & & 6.6 & & & \\
\hline 52 & Thujopsene & 1447 & & & & & & 21.8 & & & \\
\hline 53 & Aromadendrene & 1449 & & & & & & & & 1.3 & \\
\hline 54 & $\alpha$-Humulene & 1463 & & & 0.1 & 0.2 & 0.3 & & 0.1 & & \\
\hline 55 & allo-Aromadendrene & 1471 & & & & & & & & 0.6 & \\
\hline 56 & $\begin{array}{c}204[\mathrm{M}]^{+}, 119(100) \\
93(53)\end{array}$ & 1476 & & & & & & 1.0 & & & \\
\hline 57 & ar-Curcumene & 1486 & & & & & & 1.6 & & & \\
\hline 58 & Germacrene D & 1489 & & & & & 0.3 & & 1.9 & & \\
\hline 59 & cis- $\beta$-Guaiene & 1500 & & & & & & 1.1 & & & \\
\hline 60 & Ledene & 1501 & & & & & & & & 1.3 & \\
\hline 61 & $\alpha$-Muurolene & 1502 & & & & & & & 0.8 & & \\
\hline 62 & Bicyclogermacrene & 1506 & & & & & & & & 1.3 & \\
\hline 63 & $\beta$-Bisabolene & 1509 & & 0.2 & & & & & & & \\
\hline 64 & $\alpha$-Cuprenene & 1515 & & & & & & 4.0 & & & \\
\hline 65 & Cuparene & 1520 & & & & & & 7.9 & & & \\
\hline 66 & $\gamma$-Cadinene & 1520 & & & & & 1.3 & & & & \\
\hline 67 & Cubebol & 1524 & & & & & 1.0 & & & & \\
\hline 68 & $\zeta$-Cadinene & 1526 & & & & & & & & 1.4 & \\
\hline 69 & $\begin{array}{c}204[\mathrm{M}]^{+}, 173(100) \\
119(60)\end{array}$ & 1526 & & & & & & 3.8 & & & \\
\hline 70 & trans-Calamenene & 1531 & & & & & & 1.5 & & & \\
\hline 71 & $\gamma$-Cuprenene & 1545 & & & & & & 1.4 & & & \\
\hline 72 & Elemol & 1554 & & & & & & & 3.1 & & \\
\hline 73 & Carryophyllene oxide & 1592 & & 0.1 & 0.8 & 0.2 & 0.7 & & & & \\
\hline 74 & Cedrol & 1622 & & & 0.2 & & & 15.1 & & & \\
\hline 75 & 12-epi-Cedrol & 1642 & & & & & & 0.6 & & & \\
\hline 76 & $\gamma$-Eudesmol & 1645 & & & & & & 0.6 & & & \\
\hline 77 & $\alpha$-Cadinol & 1656 & & & & & & 3.1 & & & \\
\hline 78 & $\alpha$-Eudesmol & 1671 & & & & & & 1.2 & & & \\
\hline 79 & $\beta$-Bisabolol & 1679 & & & & & & 0.6 & & & \\
\hline & Total & & 95.8 & 99.7 & 98.6 & 99.6 & 99.3 & 96.7 & 91.4 & 95.4 & 99.0 \\
\hline & Monoterpene hydrocarbo & & 84.7 & 94.0 & 39.9 & 38.0 & 1.2 & & 4.4 & 42.2 & 23.4 \\
\hline & Monoterpene alcohols & & 0.8 & 0.3 & 1.6 & 58.1 & 10.4 & & 37.4 & 47.0 & 72.7 \\
\hline & Monoterpene aldehydes & & & 3.5 & & & 75.7 & & 32.9 & & \\
\hline & Monoterpene esters & & 5.2 & 0.9 & 55.3 & 0.2 & 5.6 & & 9.6 & & \\
\hline & her oxygenated monoterpe & & & 0.2 & & 0.2 & & & & & \\
\hline & Sesquiterpene hydrocarbo & & 5.1 & 0.7 & 0.8 & 2.9 & 4.7 & 75.5 & 5.0 & 6.2 & 2.9 \\
\hline & Oxygenated sesquiterpeno & & & 0.1 & 1.0 & 0.2 & 1.7 & 21.2 & 3.1 & & \\
\hline
\end{tabular}

${ }^{a}$ Retention index on ZB-5MS column; ${ }^{\mathrm{b}}$ PI-pine needle (Pinus sylvestris) EO; LE-lemon (Citrus lemon) EO; SF-silver fir (Abies alba) EO; TY—-thyme (Thymus vulgaris) EO; LG-lemongrass (Cymbopogon schoenanthus) EO; CE—cedarwood (Juniperus virginiana) EO; ME-lemon balm (Melissa officinalis) EO; MA-tea tree (Melaleuca alternifolia) EO; OR-oregano (Origanum vulgare) EO. 


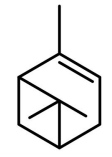

(3) $\alpha$-pinene

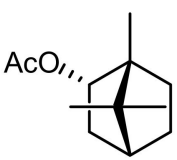

(34) bornyl acetate<smiles>C=C1CC2CC3C1CC23</smiles>

(6) $\beta$-pinene<smiles>C=C(C)C1CC=C(C)CC1</smiles>

(11) limonene

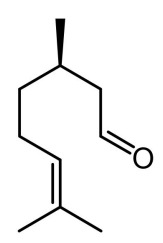

(21) citronellal<smiles>CC(C)=CCC/C(C)=C\C=O</smiles>

(29) neral<smiles>CC(C)=CCC/C(C)=C/C=O</smiles>

(33) geranial<smiles>Cc1ccc(C(C)C)c(O)c1</smiles>

(36) thymol<smiles>Cc1ccc(C(C)C)cc1O</smiles>

(37) carvacrol

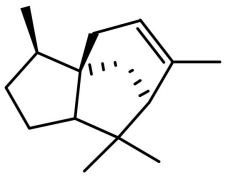

(49) $\alpha$-cedrene<smiles>CC1=CC[C@@]2(C)CCCC(C)(C)[C@@]2(C)C1</smiles>

(52) thujopsene

Figure 1. Structures of the major components present in the analyzed essential oils. Compound numbers identical to those in Table 2.

There are two EOs for which the monoterpene hydrocarbons are the most characteristic components. These are EOs obtained from Pinus sylvestris (PI) and Citrus lemon (LE). However, the major components for pine EO are $\alpha$ - (3) and $\beta$-pinene (6), belonging to bicyclic monoterpenoids, while monocyclic compound, limonene (11) is characteristic for lemon EO.

In three among nine chemically analyzed EOs, monoterpene alcohols are the predominant components. Essential oils hydrodistilled from Thymus vulgaris, Origanum vulgare, and Melaleuca alternifolia belong to this group. Thymol (36), carvacrol (37), and terpinen-4-ol (25) are the dominant compounds in these EOs, respectively. Besides alcohols, the mentioned EOs are also characteristic for the presence of monoterpene hydrocarbons. The important component of thyme and oregano EOs is $p$-cymene, while other terpinenes, like $\alpha-, \gamma$ - and $\delta$-terpinene (=terpinolene), and $\alpha$-terpineol were detected in tea tree EO.

Lemon balm EO (Melissa spp.) is another essential oil known for the presence of monotepene alcohols as the main compounds. Despite this similarity, chemical differences were evident between this EO and already mentioned thee oils. This difference concerns the second dominant group of monoterpenoids, which are aldehydes, not hydrocarbons. The most characteristic terpenes found in this EO are citronellal (21), citronellol and geraniol.

Almost $76 \%$ of all components present in the EO from lemongrass (Cymbopogon schoenanthus) are monoterpene aldehydes, and mainly two isomers, neral (29) and geranial (33). Geraniol and its acetate are the next two components of this EO that are worth mentioning. Another monoterpene ester, bornyl acetate (34) constitutes more that $53 \%$ of all volatiles present in the EO obtained from silver fir (Abies alba). This EO is also rich in hydrocarbons, e.g., $\alpha$-, $\beta$-pinene, limonene or camphene.

It has been shown that prevailing components of the pine, lemon, silver for, thyme, oregano, lemongrass, lemon balm, and tea tree EOs are monoterpenoids. This group of terpenoids constitute about $90 \%$ of all components present in all these essential oils. Sesquiterpenoids represent a small percentage of their composition. There is a completely different situation in the case of cedarwood EO (Juniperus virginiana-CE). No monoterpenoids have been identified in this oil. Almost $76 \%$ of the components present in this EO are sesquiterpene hydrocarbons, while the other compounds are sesquiterpene alcohols. The most characteristic compounds found of this EO are $\alpha$-cedrene (49) and thujopsene (52).

\subsection{Antioxidant Analysis}

The analyzed EOs showed poor antioxidative activity, as found on the basis of AAI (antioxidant activity index) $<0.5$; the values of AAI ranged from $<0.08$ to 0.114 , depending on the tested oil (Table 3 ). 
Table 3. Antioxidative activity of selected essential oils.

\begin{tabular}{ccc}
\hline Essential Oil & EC $_{\mathbf{5 0}} \pm \mathbf{S D}(\mathbf{m g} / \mathbf{m L})$ & AAI \\
\hline Oregano & $0.70+/-0.03$ & 0.114 \\
Thyme & $0.71+/-0.05$ & 0.110 \\
Lemon balm & $0.78+/-0.08$ & 0.102 \\
Tea tree & $0.93+/-0.03$ & 0.085 \\
Lemongrass & $2.74+/-0.03$ & 0.029 \\
Cedarwood & $5.16+/-0.10$ & 0.015 \\
Pine needle & $>10.00$ & $<0.08$ \\
Silver fir & $>10.00$ & $<0.08$ \\
Lemon & $>10.00$ & $<0.08$ \\
\hline
\end{tabular}

\subsection{Urease Inhibitory Analysis}

The results for the assessment of urease inhibitory activity of the EOs are listed in Table 4. It was found that the most active was cedarwood oil $\left(\mathrm{IC}_{50}=5.3 \mathrm{mg} / \mathrm{L}\right)$, inhibiting urease at subinhibitory (sub-MIC) concentrations (MIC $=15.6 \mathrm{mg} / \mathrm{L}$ ), concentration that is below the value capable of inhibiting the detectable growth and replication of a microorganism. Pine, lemon, silver fir and tea tree oils showed highly inhibitive activity for urease despite their higher MIC values. This is indicative that their subinhibitory values for bacterial growth have evident inhibitory effect against bacterial urease.

Table 4. Antibacterial activity (MIC) and inhibition of $H$. pylori urease $\left(\mathrm{IC}_{50}\right)$ by analyzed essential oils.

\begin{tabular}{ccc}
\hline Essential Oil & IC $\left._{\mathbf{5 0}} \mathbf{( m g} / \mathbf{L}\right)$ & MIC $(\mathbf{m g} / \mathbf{L})$ \\
\hline Cedarwood & 5.3 & 15.6 \\
Pine needle & 18.4 & 125 \\
Lemon & 35.6 & 125 \\
Silver fir & 37.9 & 125 \\
Tea tree & 39.1 & 62.5 \\
Lemongrass & 67.1 & 15.6 \\
Oregano & 208.3 & 31.3 \\
Thyme & 248.7 & 15.6 \\
Lemon balm & $>1049.9$ & 15.6 \\
\hline
\end{tabular}

Lemongrass, oregano, thyme oils demonstrated weaker urease inhibitory activity even though their MIC values showed strong inhibitory effects of $H$. pylori growth. Melissa oil did not inhibit the urease activity at concentrations used $\left(\mathrm{IC}_{50}>1049.9 \mathrm{mg} / \mathrm{L}\right)$.

\subsection{In Vitro Antimicrobial Activity of Selected Essential Oils against Clinical H. pylori Strains}

The antimicrobial activity of the nine selected EOs was evaluated against 22 clinical strains including sensitive to antibiotics (10 stains) and 12 resistant strains to at least 1 antibiotic (metronidazole, rifampicin, clarithromycin, tetracycline or levofloxacin). The EOs activity was defined on the basis of $\mathrm{MIC}_{50}$ and $\mathrm{MIC}_{90}$, i.e., MIC values inhibiting 50 or $90 \%$ of the studied clinical strains, respectively. The most active were cedarwood and oregano oils with $\mathrm{MIC}_{90}=62.5 \mathrm{mg} / \mathrm{L}$. Less active were thyme, lemongrass and lemon balm oils ( $\mathrm{MIC}_{90}=125 \mathrm{mg} / \mathrm{L}$ ), followed by tea tree, lemon, pine needle and silver fir oils ( $\mathrm{MIC}_{90}=250 \mathrm{mg} / \mathrm{L}$ ). It was shown that antibiotic susceptibility of clinical H. pylori strains has no impact on the antibacterial activity of the tested EOs (Figure 2). 


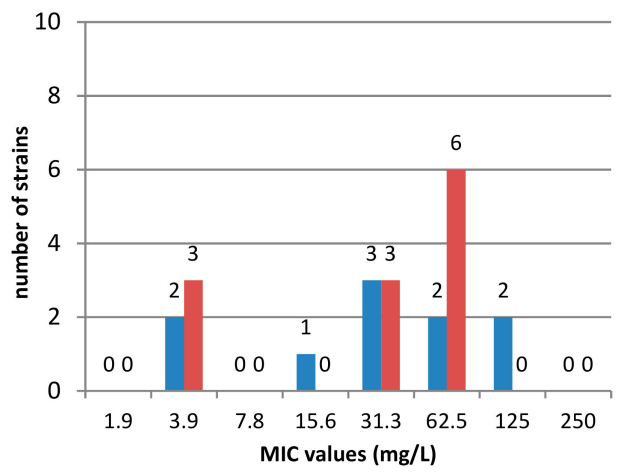

(a)

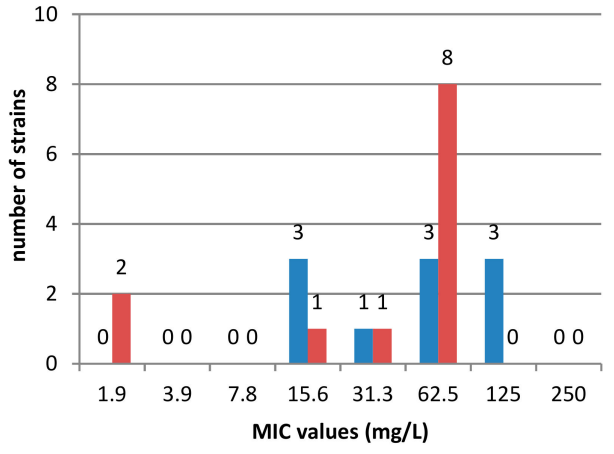

(c)

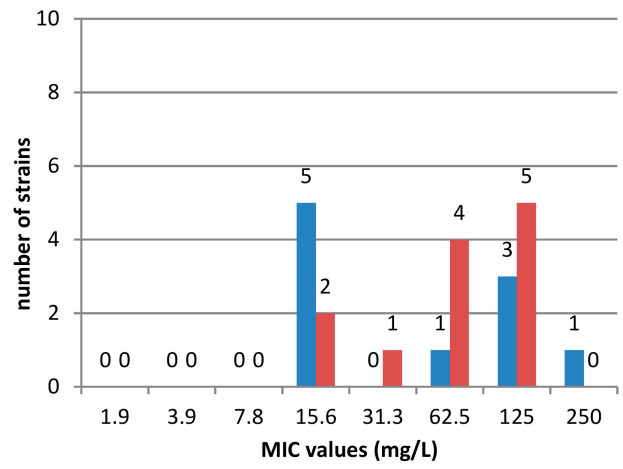

(e)

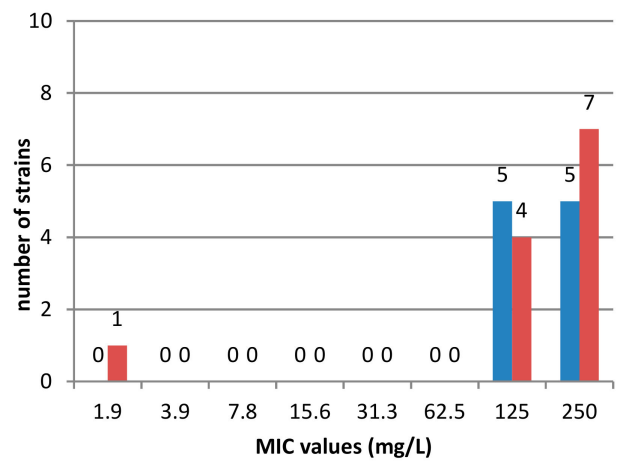

(g)

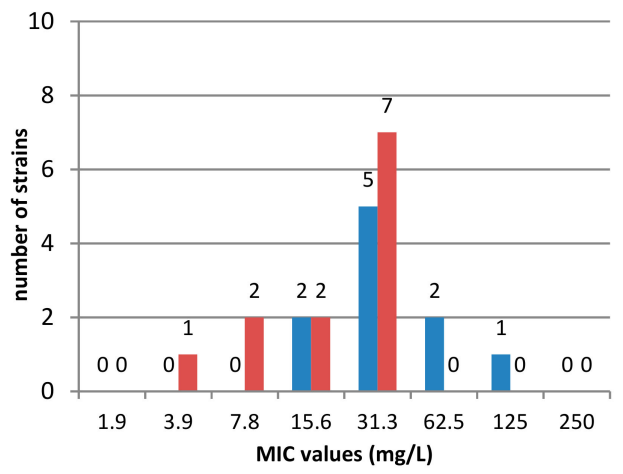

(b)

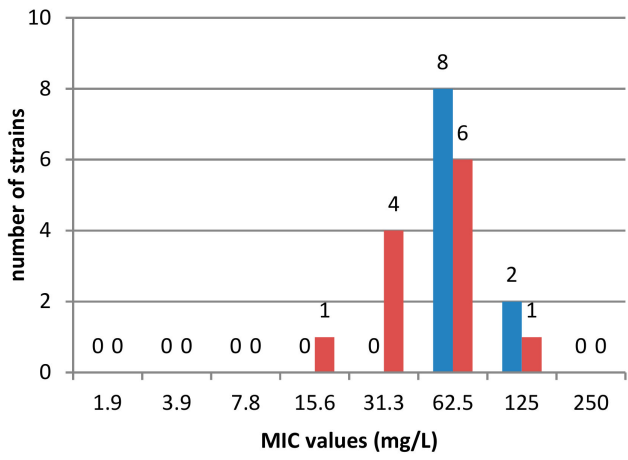

(d)

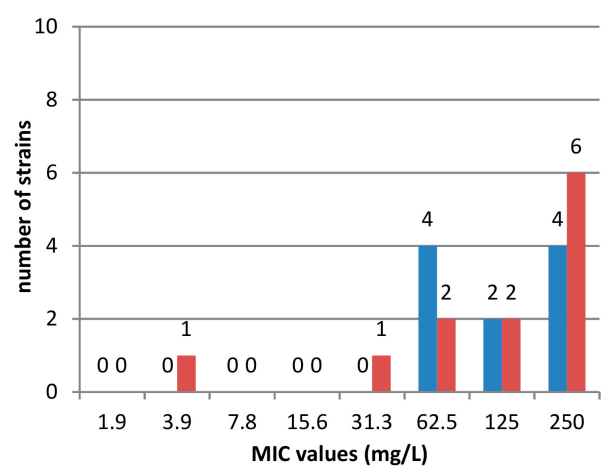

(f)

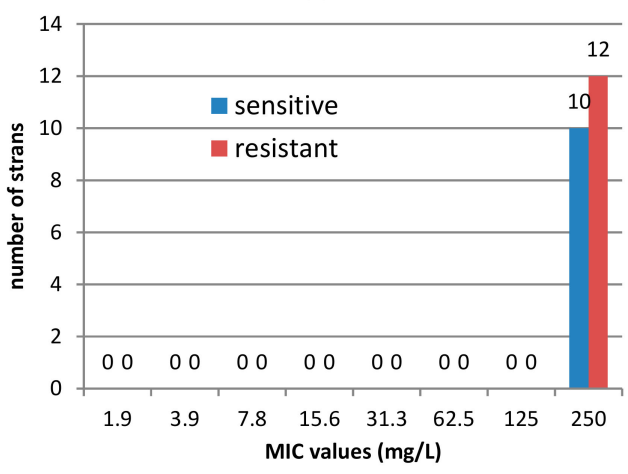

(h)

Figure 2. Susceptibility of 22 clinical H. pylori strains to essential oils in MIC values (mg/L): (a) cedarwood oil; (b) oregano oil; (c) thyme oil; (d) lemongrass oil; (e) lemon balm oil; (f) tea tree oil; (g) lemon oil; (h) pine and fir oils. 
2.6. Principal Component Analysis (PCA) of Phytochemical Composition and Biological Properties against H. pylori Strain of the Analyzed Essential Oils

The statistical analysis by PCA allowed to the division of the oils into three phytochemical groups differing in their anti-H. pylori activity (Figure 3, Table 5).

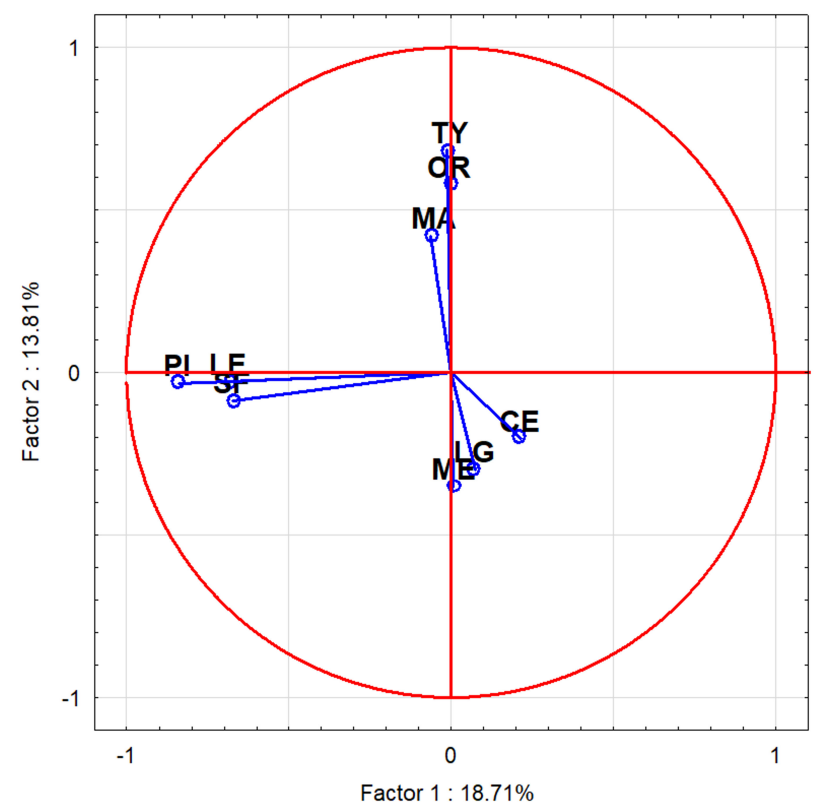

Figure 3. Principal component analysis of 9 analyzed essential oils based on their chemical composition. PI—pine needle EO; LE-lemon EO; SF—silver fir EO; TY-thyme EO; LG-lemongrass $\mathrm{EO} ; \mathrm{CE}$-cedarwood EO; ME—lemon balm EO; $\mathrm{MA}$ - tea tree EO; OR-oregano EO.

Table 5. Biological activity of essential oils in relation to principal component analysis (PCA) groups.

\begin{tabular}{|c|c|c|c|c|c|}
\hline \multirow{2}{*}{ PCA Group. } & \multirow[b]{2}{*}{ Essential Oil } & \multicolumn{2}{|c|}{ MIC (mg/L) } & \multirow{2}{*}{$\begin{array}{l}\text { Urease Inhibitory } \\
\text { Activity } \mathrm{IC}_{50}(\mathrm{mg} / \mathrm{L})\end{array}$} & \multirow[b]{2}{*}{ AAI } \\
\hline & & $\begin{array}{c}\text { H. pylori } \\
\text { ATCC } 43504\end{array}$ & $\begin{array}{c}\mathrm{MIC}_{50 / 90} \text { for Clinical } \\
\text { H. pylori Strains }\end{array}$ & & \\
\hline \multirow{3}{*}{ I } & Silver fir & 125 & $250 / 250$ & 37.9 & $<0.08$ \\
\hline & Pine needle & 125 & $250 / 250$ & 18.4 & $<0.08$ \\
\hline & Lemon & 125 & $250 / 250$ & 35.6 & $<0.08$ \\
\hline \multirow{3}{*}{ II } & Oregano & 31.3 & $31.3 / 62.5$ & 208.3 & 0.114 \\
\hline & Thyme & 15.6 & $62.5 / 125$ & 248.7 & 0.110 \\
\hline & Tea tree & 125 & $125 / 250$ & 39.1 & 0.085 \\
\hline \multirow{3}{*}{ III } & Lemongrass & 15.6 & $62.5 / 125$ & 67.1 & 0.029 \\
\hline & Lemon balm & 15.6 & $62.5 / 125$ & $>1049.9$ & 0.102 \\
\hline & Cedarwood & 15.6 & $31.3 / 62.5$ & 5.3 & 0.015 \\
\hline
\end{tabular}

Group I included oils of similar chemical composition: silver fir, pine needle and lemon oils. The components present in these EOs belonged mainly to monoterpene hydrocarbons in pine and lemon oils. Silver fir oil also consisted of monoterpene esters (i.e., bornyl acetate), but without any influence on its bioactivity. EOs included in this group had the lowest anti-H. pylori and antioxidant activity but high inhibitory activity against bacterial urease. Group II consisted of EOs with quite similar chemical composition, containing: $\alpha$-terpinene, $p$-cymene i $\gamma$-terpinene, but differed in the main components - carvacrol for oregano oil, terpinen-4-ol for tea tree oil and thymol for thyme oil. Bioactivity of this group was diversified. Group III included oils of different chemical composition. Main components of lemongrass and lemon balm EOs belonged to monoterpene alcohols and aldehydes in different proportion explaining the differences in their antioxidant and urease inhibitory activity. The composition of cedarwood oil was quite different from all chemically investigated EOs; the main 
components were sesquiterpenoids, e.g., $\alpha-, \beta$-cedrene, thujopsene, cedrol, cuparene. This group presented the highest efficacy of H. pylori growth inhibition both reference and clinical strains (Table 5).

\section{Discussion}

Plant essential oils and extracts have been used for many thousands of years in food preservation, pharmaceuticals, alternative medicine and natural therapies [13]. Studies indicate that essential oils have bactericidal effects against several microorganisms [14-16]. However, differences in the bactericidal activity among essential oils were observed. We screened 26 different commercial essential oils for their anti-Helicobacter properties by determination of inhibitory and bactericidal activity. The highest activity against reference $H$. pylori strain revealed cedarwood, lemongrass, thyme, lemon balm no. 2 , Ylang-Ylang and basil oils. According to bioactivity criteria established by O'Donnell et al. [17] these EOs presented strong bioactivity against $H$. pylori. The rest of the EOs exhibited good bioactivity showing MIC range of 26-125 mg/L. Out of 26 EOs 9 oils demonstrating different MIC values were chosen to display a correlation between a chemical composition and bioactivity of EO.

The activity of essential oils against $H$. pylori was reported before [11] and among the 13 essential oils tested for H. pylori growth inhibition, Cymbopogon citratus (lemongrass) and Lippia citriodora (lemon verbena) were demonstrated to have the highest bactericidal activities for $H$. pylori strain ATCC 49503 [18]. Bergonzelli et al. [8] evaluated the activities of 60 essential oils against $H$. pylori showing that 30 oils were able to affect the growth in vitro and 15 showed strong activity. Among compounds of these oils, carvacrol, isoeugenol, nerol, citral (=neral + geranial) and sabinene exhibited the strongest anti-H. pylori effects. In our study, it was shown that prevailing components of the pine needle, lemon, silver fir, thyme, oregano, lemongrass, lemon balm, and tea tree EOs are monoterpenoids. This group of terpenoids constitutes about $90 \%$ of all components present in all these essential oils. Sesquiterpenoids represent a small percentage of their composition. Terpenoids are weakly to moderately soluble in water, but they are dissolvable in the phospholipid membrane. The antimicrobial activities of terpenoids are assumed to be due to their ability to disrupt or penetrate lipid structure causing a loss of membrane integrity, dissipation of the proton motive force and impairment of intracellular pH homeostasis $[19,20]$. However, the different composition within the monoterpenoids group was correlated with different MIC values of EOs. In PCA group I, with the weakest anti-H. pylori activity among the tested EOs, monoterpene hydrocarbons were the dominating compounds, indicating barely good bioactivity against $H$. pylori. In PCA group II, despite the little difference, MIC values of EOs were higher than in group I, possibly due to the content of monoterpene alcohols. The higher content of the alcohols, the higher the MIC values that were observed. Thymol is reported to be a strong antimicrobial agent of which hydroxyl group and delocalized electrons are responsible for damaging the cytoplasmic membrane [20], interacting with membrane and intracellular proteins and changing the membrane permeability, the leakage of potassium ions and ATP [21,22] of other bacteria. Carvacrol could act by disruption and depolarization of the plasma membrane by targeting membrane proteins and intracellular drug target and was recognized as a strong inhibitive against $H$. pylori, but in the presence of thymol, the antibacterial effect of carvacrol was found to be reduced [23]. In our study, the EOs containing thymol (thyme EO) or carvacrol (oregano EO) as the main component, with the other one being found in trace amounts. Other components identified in EOs from PCA group II, including $\gamma$-terpinene, 1,8 -cineole, $\alpha$-pinene, $\beta$-pinene, p-cymene, have been shown, in other studies, to have no antibacterial activity against Gram negative bacteria [24-27]. Furthermore, it has been reported that some components with no antibacterial activity in the presence of some antimicrobial agents show a synergistic effect [28], for example, the presence of $p$-cymene along with carvacrol may enhance the antimicrobial activity of the oil [27].

The PCA group III consists of the EOs with the highest anti-H. pylori activity; however, for lemongrass and lemon balm EOs, the activity comes from the monoterpene alcohols and aldehydes content. In other studies, geranial and neral in lemongrass and lemon verbena EOs were marked also as components possessing heightened anti-H. pylori bactericidal effects compared to other 
components [11]. In the case of cedarwood EO (Juniperus virginiana), there was a completely different situation. No monoterpenoids were identified in this oil. Sesquiterpenoids are the dominant group of terpenoids present in this EO, and among them $\alpha$-cedrene and thujopsene are the most characteristic compounds. There have been no reports on the biological activity of cedarwood $\mathrm{EO}$ and its compounds against $H$. pylori to date. However, there is published data about the anti-H. pylori activity of patchouli alcohol [29], which belongs to the group of tricyclic sesquiterpenoids, similarly for the major components present in cedarwood oil. It has been reported that its antibacterial activity against Streptococcus mutans [30] and antifungal properties are based on DNA polymerase inhibition [31]. In our study, cedarwood oil was one of the most potent EOs.

In our study, cedarwood EO was also the most effective inhibitor of $H$. pylori urease. It might be speculated that one of sesquiterpene hydrocarbons or alcohols or their synergistic activity exhibit very strong activity against bacterial urease. Nonetheless, the activity of individual EOs components is necessary to determine. Urease inhibition may be the main defense against H. pylori due to prevention from adhering it to the gastric mucosa. Previous studies revealed the isolation of urease inhibitors from some plants and herbs [32-34]. It was found that the mechanism of urease inhibition is noncompetitive, in which both inhibitor and the substrate were attached to the enzyme non-competitively. Some flavonoids have demonstrated inhibitory effects on $H$. pylori urease [35-38]. To date, there are no studies related to analyses of essential oils towards $H$. pylori urease inhibition. Our study demonstrated that even EOs with barely good inhibitory activity against $H$. pylori growth present strong or very strong inhibitory activity against urease. This means that subinhibitory concentration of EOs could be effective in the treatment of $H$. pylori infection since urease is essential for its colonization; therefore, the inhibition of this enzyme partly explains the anti-H. pylori activity.

In the radical scavenging activity assay, the tested EOs displayed weak activity. Essential oils are quite complex mixtures composed of a variety of compounds, which is why it is difficult to explain their activities. The antioxidant activity is generally related to the major active compounds in essential oils such as eugenol in clove [39], carvacrol in oregano [40], thymol in thyme [41], and citronellol or citronellal in citronella [42]. In our study, EOs included in PCA group II (thyme, oregano and tea tree EOs) presented the highest antioxidative activity. However, the other antioxidant compounds in essential oils such as terpinene, bornyl acetate, and eucalyptol have been reported to present antioxidant activity, but their amounts were probably too low to exhibit antioxidant activity [42,43]. Antioxidant activity of essential oil varies with source of essential oils and is also affected by extraction method or solvents used. Additionally, the harvesting period of the plant also determines the concentration of the major oil components such as phenolic compounds, which is directly related to the antioxidant activity of essential oils [16].

H. pylori infection preceded by gastric mucosa colonization is associated with the production of reactive oxygen and nitrogen forms. Therefore, the use of antioxidants can be regarded as a complementary therapy in $H$. pylori eradication [44]. The use of functional food and dietary supplements containing the substances with high antioxidant activity can strengthen the protective properties of the body and inhibit $H$. pylori multiplication [45]. In addition, most studies proved that H. pylori infection affects the level of antioxidants in gastric juice. Experimental studies, both in vivo and in vitro, have shown that substances with strong antioxidant properties such as vitamin $\mathrm{C}$ and astaxanthin not only scavenge free radicals, but also show antimicrobial activity against $H$. pylori [46,47].

The use of essential oils of cedarwood, oregano, lemongrass, lemon balm may contribute to an efficient control of $H$. pylori that is spread among the world population. Moreover, due to the increase of the multiresistance pattern and also to the increasing tendency of the public to consume 'green products', the use of these types of compounds will support treatment of $H$. pylori infection and so may help to reduce the transmission of this pathogen from asymptomatic carriers. 


\section{Materials and Methods}

\subsection{Essential Oils}

The essential oils were obtained from several commercial sources available in Polish market (Table 1 ) and kept at $4{ }^{\circ} \mathrm{C}$. They were tested dissolve in $100 \%$ dimethyl sulfoxide (DMSO).

\subsection{Analysis of Essential Oils}

Two $\mu \mathrm{L}$ of nine essential oils were diluted to $1 \mathrm{~mL}$ by $n$-hexane. One $\mu \mathrm{L}$ of the essential oil solutions was analyzed by GC-MS using a Shimadzu GC-2010 Plus gas chromatography instrument coupled to a Shimadzu QP2010 Ultra mass spectrometer (Shim-Pol, Izabelin, Poland). Compounds were separated on a fused silica capillary column ZB-5MS (30 m, $0.25 \mathrm{~mm}$ i.d.) with a film thickness of $0.25 \mu \mathrm{m}$ (Phenomenex, Torrance, CA, USA). The following oven temperature program was initiated at $50{ }^{\circ} \mathrm{C}$, held for $3 \mathrm{~min}$, then increased at the rate of $8{ }^{\circ} \mathrm{C} / \mathrm{min}$ to $250{ }^{\circ} \mathrm{C}$, held for $2 \mathrm{~min}$. The spectrometers were operated in electron-impact (EI) mode, the scan range was 40-500 amu, the ionization energy was $70 \mathrm{eV}$, and the scan rate was $0.20 \mathrm{~s}$ per scan. Injector, interface and ion source were kept at 250, 250 and $220^{\circ} \mathrm{C}$, respectively. Split injection $(1 \mu \mathrm{L})$ was conducted with a split ratio of 1:20 and helium was used as carrier gas of $1.0 \mathrm{~mL} / \mathrm{min}$ flow-rate. The retention indices were determined in relation to a homologous series of n-alkanes (C8-C20) under the same operating conditions. Compounds were identified using a computer-supported spectral library (NIST 2011 - Gaithersburg, MD, USA; MassFinder 2.1 and 4.0-Hamburg, Germany), mass spectra of reference compounds, as well as MS data from the literature $[48,49]$.

\subsection{Antioxidant Assay}

Determination of 2,2-diphenyl-1-picrylhydrazyl (DPPH) activity was carried out according to the method described by Brand-Williams et al. [50] with modifications. Various dilutions of extracts (5-125 $\mu \mathrm{g} / \mathrm{mL})$ and butylated hydroxytoluene (BHT) $(2-30 \mu \mathrm{g} / \mathrm{mL})$ as a positive control were used for antioxidant assay. $100 \mu \mathrm{L}$ of each of the tested extracts or BHT were mixed with $100 \mu \mathrm{L}$ of ethanolic solution of DPPH $(32 \mu \mathrm{g} / \mathrm{mL})$ in 96 well plates. Plates were incubated in the dark at room temperature for 30 minutes after 10 seconds of shaking. Before being measured, the plates were re-shaken for 60 seconds. The absorbance was measured using a BioTek ELx808 reader (BioTek Instruments, Inc, Winooski, VT, USA) at $515 \mathrm{~nm}$. The $\mathrm{EC}_{50}$ values (concentration at which the DPPH absorbance is reduced by 50\%) were calculated by Gen5 software version 2.01 (BioTek Instruments, Inc, Winooski, VT, USA) five logistic parameters (5LP) according to the equation:

$$
\mathrm{Y}=\mathrm{D}+(\mathrm{A}-\mathrm{D}) /\left(\left(1+(\mathrm{x} / \mathrm{C})^{\wedge} \mathrm{B}\right)^{\wedge} \mathrm{E}\right)
$$

where: $A-$ minimal curve asymptote; $B-$ measure of slope of curve at its inflection point, $C-$ value of $\mathrm{x}$ at inflection time; $D$-maximal curve asymptote; $E$-quantifies the asymmetry; $\mathrm{x}$ concentration, $Y$-response.

The antioxidant activity index (AAI) was calculated according to the method proposed by Scherer and Godoy [51], were:

$$
\mathrm{AAI}=\text { final DPPH concentration }(\mu \mathrm{g} / \mathrm{mL}) / \mathrm{EC}_{50}(\mu \mathrm{g} / \mathrm{mL})
$$

Antioxidant activity EOs was assessed according to the following scale: poor antioxidant activity when AAI < 0.5, moderate antioxidant activity when AAI between 0.5 and 1.0, strong antioxidant activity when AAI between 1.0 and 2.0, and very strong when AAI > 2.0 [16].

The assays were carried out in triplicate and all the samples and standard solutions, as well as the DPPH solutions, were prepared daily. 


\subsection{Bacteria}

H. pylori ATCC 43504 was obtained from American Type Culture Collection (Rockville, MD, USA). The 22 clinical $H$. pylori strains used in the study were isolated from patients with gastrointestinal disorders, tested and described elsewhere [52]. Ten strains were susceptible to all tested antibiotics and out of 12 strains 4 strains were resistant to 1 antibiotic (metronidazole or rifampicin), 6 strains were resistant to 2 antibiotics (clarithromycin + metronidazole; clarithromycin + rifampicin; metronidazole + rifampicin; metronidazole + levofloxacin), 1 strain was resistant to clarithromycin + levofloxacin + metronidazole and 1 strain was resistant to clarithromycin + levofloxacin + metronidazole + rifampicin.

\subsection{Antimicrobial Activity Testing}

The strains were obtained during 72-h cultivation in the brain heart infusion agar (BHA, Becton Dickinson, Germany) $+7 \%$ horse blood in microaerophilic conditions $\left(5 \% \mathrm{O}_{2}, 15 \% \mathrm{CO}_{2}\right.$ and $\left.80 \% \mathrm{~N}_{2}\right)$. Cell concentration was determined using a densitometer (BioMerieux, Marcy l'Etoile, France). Bacterial suspensions with a density of three according to the McFarland scale, i.e., $3 \times 10^{8}$ cells (CFU)/ $1 \mathrm{~mL}$ were used for the tests. Essential oils were screened for antibacterial activities by microdilution broth method according to the European Committee on Antimicrobial Susceptibility Testing (EUCAST) (www.eucast.org) using Mueller-Hinton broth with 5\% lysed horse blood. Minimal Inhibitory Concentration (MIC) of the tested essential oils were evaluated for all $H$. pylori strains with method modification by addition after incubation of resazurin to visualize the growth of $H$. pylori. Appropriate DMSO control (at a final concentration of $10 \%$ ), a positive control (containing inoculum without the tested essential oils) and negative control (containing the tested essential oils without inoculum) were included on each microplate.

Minimal bactericidal concentration (MBC) was determined by subculturing $5 \mu \mathrm{L}$ of the microbial culture from each well that showed growth inhibition, from the last positive one and from the growth control onto the recommended agar plates. The plates were incubated at $35{ }^{\circ} \mathrm{C}$ for $72 \mathrm{~h}$ in microaerophilic conditions and the MBC was defined as the lowest concentration of the essential oil without growth of microorganism. Each experiment was triplicated. Representative data is presented.

\subsection{Urease Inhibitory Effect}

Urease inhibitory effect was measured via the alkalimetric method developed by Hamilton Miller and Gargan (1979) and Mobley et al. (1988) for urease preparations of H. pylori ATCC 43504 strain in the presence of urease inhibitors. In a 96-well plate, $10 \mu \mathrm{L}$ of bacterial suspension ( $3 \mathrm{McF}$ arland) was mixed with various concentrations of inhibitors (range $250-1.95 \mathrm{mg} / \mathrm{L}$ ) in urea medium $(0.1 \mathrm{~g} / \mathrm{L}$ yeast extract, $9.1 \mathrm{~g} / \mathrm{L} \mathrm{KH} \mathrm{PO}_{4}, 9.5 \mathrm{~g} / \mathrm{L} \mathrm{Na}{ }_{2} \mathrm{HPO}_{4}, 20 \mathrm{~g} / \mathrm{L}$ urea and $0.01 \mathrm{~g} / \mathrm{L}$ phenol red) and mixed thoroughly. After $24 \mathrm{~h}$ of incubation at $35^{\circ} \mathrm{C}$ in microaerophilic conditions, absorbance was measured at $560 \mathrm{~nm}$ (BioTEK ELx808, BioTek Instruments, Inc, Winooski, VT, USA). The concentration of the inhibitor required to diminish enzyme activity by $50 \%\left(\mathrm{IC}_{50}\right)$ was calculated by plotting percent inhibition against the concentration of inhibitor (Gen5 software, BioTek Instruments, Inc, Winooski, VT, USA). One hundred percent activity was determined in the absence of inhibitor.

\subsection{Statistical Analysis}

All analyses were performed in triplicates in order to prove their reproducibility. The results of antioxidant assays were expressed as mean \pm standard deviations (SD). The representative results for antimicrobial activity testing were presented. Principal component analysis (PCA) was performed using STATISTICA 13 (StatSoft. Inc., Tulsa, OK, USA).

\section{Conclusions}

The activity in vitro of the five essential oils silver fir, pine needle, tea tree, lemongrass, and cedarwood oils against $H$. pylori was found in this paper for the first time. The most active against 
clinical strains of H. pylori were cedarwood and oregano oils. Moreover, cedarwood oil inhibited the urease activity at sub-inhibitory concentrations. This essential oil can be regarded as a useful component of the plant preparations supporting the eradication H. pylori therapy.

Author Contributions: All authors have read and agree to the published version of the manuscript. Conceptualization, A.M. and I.K.-G.; methodology, I.K.-G., A.L., T.B.; formal analysis, A.M., A.G.-L., T.B., A.L., I.K.-G.; investigation, A.G.-L., I.K.-G., T.B., A.L.; resources, A.M.; writing-original draft preparation, I.K.-G., A.L., T.B., A.G.-L.; writing—review and editing, A.M., I.K.-G; supervision, A.M.; project administration, A.M.

Funding: This research received no external funding.

Conflicts of Interest: The authors declare no conflict of interest.

\section{References}

1. Makola, D.; Petura, D.A.; Crowe, S.E. Helicobacter pylori infection and related gastrointestinal diseases. J. Clin. Gastroenterol. 2007, 41, 548-558. [CrossRef] [PubMed]

2. Malfertheiner, P.; Megraud, F.; O’Morain, C.A.; Gisbert, J.P.; Kuipers, E.J.; Axon, A.T.; Bazzoli, F.; Gasbarrini, A.; Atherton, J.; Graham, D.Y.; et al. Management of Helicobacter pylori infection - the Maastricht V/ Florence consensus report. Gut 2017, 66, 646-664. [CrossRef] [PubMed]

3. Molina-Infante, J.; Perez-Gallardo, B.; Fernandez-Bermejo, M.; Hernandez-Alonso, M.; Vinagre, G.; Dueñas, C.; Mateos-Rodriguez, J.M.; Gonzalez-Garcia, G.; Abadia, E.G.; Gisbert, J.P. Clinical trial: Clarithromycin vs. levofloxacinin first-line triple and sequential regiments for Helicobacter pylori eradication. Aliment Pharmacol. Ther. 2010, 31, 1077-1084. [CrossRef] [PubMed]

4. Follmer, C. Ureases as a target for the treatment of gastric and urinary infections. J. Clin. Pathol. 2010, 63, 424-430. [CrossRef] [PubMed]

5. Vale, F.F.; Oleastro, M. Overview of the phytomedicine approaches against Helicobacter pylori. World J. Gastroenterol. 2014, 20, 5594-5609. [CrossRef]

6. Wang, Y.C. Medicinal plant activity on Helicobacter pylori related diseases. World J. Gastroenterol. 2014, 20, 10368-10382. [CrossRef]

7. Aziz, Z.A.A.; Ahmad, A.; Setapar, S.H.M.; Karakucuk, A.; Azim, M.M.; Lokhat, D.; Rafatullah, M.; Ganash, M.; Kamal, M.A.; Ashraf, G.M. Essential Oils: Extraction Techniques, Pharmaceutical And Therapeutic Potential - A Review. Curr. Drug Metab. 2018, 19, 1100-1110. [CrossRef]

8. Bergonzelli, G.E.; Donnicola, D.; Porta, N.; Corthésy-Theulaz, I.E. Essential oils as components of a diet-based approach to management of Helicobacter infection. Antimicrob. Agents Chemother. 2003, 47, 3240-3246. [CrossRef]

9. Bonifácio, B.V.; dos Santos Ramos, M.A.; da Silva, P.B.; Bauab, T.M. Antimicrobial activity of natural products against Helicobacter pylori: A review. Ann. Clin. Microbiol. Antimicrob. 2014, 13, 54. [CrossRef]

10. Miguel, G.; Faleiro, L.; Cavaleiro, C.; Salgueiro, L.; Casanova, J. Susceptibility of Helicobacter pylori to essential oil of Dittrichia viscosa subsp. revoluta. Phytother. Res. 2008, 22, 259-263. [CrossRef]

11. Ohno, T.; Kita, M.; Yamaoka, Y.; Imamura, S.; Yamamoto, T.; Mitsufuji, S.; Kodama, T.; Kashima, K.; Imanishi, J. Antimicrobial activity of essential oils against Helicobacter pylori. Helicobacter 2003, 8, 207-215. [CrossRef] [PubMed]

12. Harmati, M.; Gyukity-Sebestyen, E.; Dobra, G.; Terhes, G.; Urban, E.; Decsi, G.; Mimica-Dukic, N.; Lasjak, M.; Simin, N.; Pap, B.; et al. Binary mixture of Satureja hortensis and Origanum vulgare subsp. hirtum essential oils: in vivo therapeutic efficiency against Helicobacter pylori infection. Helicobacter 2017, 22. [CrossRef] [PubMed]

13. Valdivieso-Ugarte, M.; Gomez-Llorente, C.; Plaza-Díaz, J.; Gil, Á. Antimicrobial, Antioxidant, and Immunomodulatory Properties of Essential Oils: A Systematic Review. Nutrients 2019, 11, E2786. [CrossRef] [PubMed]

14. D'agostino, M.; Tesse, N.; Frippiat, J.P.; Machouart, M.; Debourgogne, A. Essential Oils and Their Natural Active Compounds Presenting Antifungal Properties. Molecules 2019, 24, 3713. [CrossRef] [PubMed]

15. Lang, G.; Buchbauer, G. A review on recent research result (2018-2010) on essential oils as antimicrobials and antifungals. A review. Flavour. Fragr. J. 2012, 27, 13-39. [CrossRef] 
16. Tongnuanchan, P.; Benjakul, S. Essential oils: Extraction, bioactivities, and their uses for food preservation. J Food Sci. 2014, 79, R1231-R1249. [CrossRef]

17. O'Donnell, F.; Smyth, T.J.P.; Ramachandran, V.N.; Smyth, W.F. A study of the antimicrobial activity of selected synthetic and naturally occurring quinolines. Int. J. Antimicrob. Agents 2009, 35, 30. [CrossRef]

18. Preuss, H.G.; Echard, B.; Enig, M.; Brook, I.; Elliott, T.B. Minimum inhibitory concentrations of herbal essential oils andmonolaurin for gram-positive and gram-negative bacteria. Mol. Cell Biochem. 2005, 272, 29-34. [CrossRef]

19. Prabuseenivasan, S.; Jayakumar, M.; Ignacimuthu, S. In vitro antibacterial activity of some plant essential oils. BMC Complement Altern Med. 2006, 6, 39. [CrossRef]

20. Sikkema, J.; De Bont, J.A.M.; Poolman, B. Interactions of cyclic hydrocarbons with biological membranes. J Biol Chem. 1994, 269, 8022-8028.

21. Veldhuizen, E.J.; Tjeerdsma-van Bokhoven, J.L.; Zweijtzer, C.; Burt, S.A.; Haagsman, H.P. Structural requirements for the antimicrobial activity of carvacrol. J. Agric. Food Chem. 2006, 54, 1874-1879. [CrossRef] [PubMed]

22. Xu, J.; Zhou, F.; Ji, B.P.; Pei, R.S.; Xu, N. The antibacterial mechanism of carvacrol and thymol against Escherichia coli. Lett. Appl. Microbiol. 2008, 47, 174-179. [CrossRef] [PubMed]

23. Falsafi, T.; Moradi, P.; Mahboubi, M.; Rahimi, E.; Momtaz, H.; Hamedi, B. Chemical composition and anti-Helicobacter pylori effect of Satureja bachtiarica Bunge essential oil. Phytomedicine 2015, 22, 173-177. [CrossRef]

24. Cox, S.D.; Mann, C.M.; Markham, J.L. Interactions between components of the essential oil of Melaleuca alternifolia. J. Appl. Microbiol. 2001, 91, 492-497. [CrossRef]

25. Juven, B.J.; Kanner, J.; Schved, F.; Weisslowicz, H. Factors that interact with the antibacterial action of thyme essential oil and its active constituents. J. Appl. Bacteriol. 1994, 76, 626-631. [CrossRef]

26. Andrews, R.E.; Parks, L.W.; Spence, K.D. Some effects of douglas fir terpenes on certain microorganisms. Appl. Environ. Microbiol. 1980, 40, 301-304. [CrossRef]

27. Ultee, A.; Bennik, M.H.; Moezelaar, R. The phenolic hydroxyl group of carvacrol is essential for action against the food-borne pathogen Bacillus cereus. Appl. Environ. Microbiol. 2002, 68, 1561-1568. [CrossRef]

28. Ben, H.A.; Ben, H.N. Essential oil from Artemisia phaeolepis: Chemical composition and antimicrobial activities. J. Oleo Sci. 2013, 62, 973-980. [CrossRef]

29. Xu, Y.F.; Lian, D.W.; Chen, Y.Q.; Cai, Y.F.; Zheng, Y.F.; Fan, P.L.; Ren, W.K.; Fu, L.J.; Li, Y.C.; Xie, J.H.; et al. In Vitro and In Vivo Antibacterial Activities of Patchouli Alcohol, a Naturally Occurring Tricyclic Sesquiterpene, against Helicobacter pylori Infection. Antimicrob. Agents Chemother. 2017, 61, e00122-17. [CrossRef]

30. Chaudhari, L.K.; Jawale, B.A.; Sharma, S.; Sharma, H.; Kumar, C.D.; Kulkarni, P.A. Antimicrobial activity of commercially available essential oils against Streptococcus mutans. J. Contemp. Dent. Pract. 2012, 13, 71-74. [CrossRef]

31. Takao, Y.; Kuriyama, I.; Yamada, T.; Mizoguchi, H.; Yoshida, H.; Mizushina, Y. Antifungal properties of Japanese cedar essential oil from waste wood chips made from used sake barrels. Mol. Med. Rep. 2012, 5, 1163-1168. [CrossRef] [PubMed]

32. Matongo, F.; Nwodo, U.U. In vitro assessment of Helicobacter pylori urease inhibition by honey fractions. Arch. Med. Res. 2014, 45, 540-546. [CrossRef] [PubMed]

33. Tariq, S.A.; Ahmad, M.N.; Obaidullah; Khan, A.; Choudhary, M.I.; Ahmad, W.; Ahmad, M. Urease inhibitors from Indigofera gerardiana Wall. J. Enzyme Inhib. Med. Chem. 2011, 26, 480-484. [CrossRef] [PubMed]

34. Amin, M.; Anwar, F.; Naz, F.; Mehmood, T.; Saari, N. Anti-Helicobacter pylori and urease inhibition activities of some traditional medicinal plants. Molecules 2013, 18, 2135-2149. [CrossRef]

35. Pastene, E.; Speisky, H.; García, A.; Moreno, J.; Troncoso, M.; Figueroa, G. In vitro and in vivo effects of apple peel polyphenols against Helicobacter pylori. J. Agric. Food Chem. 2010, 58, 7172-7179. [CrossRef]

36. Pastene, E.; Troncoso, M.; Figueroa, G.; Alarcón, J.; Speisky, H. Association between polymerization degree of apple peel polyphenols and inhibition of Helicobacter pylori urease. J. Agric. Food Chem. 2009, 57, 416-424. [CrossRef]

37. Lin, Y.T.; Kwon, Y.I.; Labbe, R.G.; Shetty, K. Inhibition of Helicobacter pylori and associated urease by oregano and cranberry phytochemical synergies. Appl. Environ. Microbiol. 2005, 71, 8558-8564. [CrossRef] 
38. Quílez, A.; Berenguer, B.; Gilardoni, G.; Souccar, C.; de Mendonça, S.; Oliveira, L.F.; Martín-Calero, M.J.; Vidari, G. Anti-secretory, anti-inflammatory and anti-Helicobacter pylori activities of several fractions isolated from Piper carpunya Ruiz \& Pav. J. Ethnopharmacol. 2010, 128, 583-589. [CrossRef]

39. Wei, A.; Shibamoto, T. Antioxidant/lipoxygenase inhibitory activities and chemical compositions of selected essential oils. J. Agric. Food Chem. 2010, 58, 7218-7225. [CrossRef]

40. Bounatirou, S.; Smiti, S.; Miguel, M.G.; Faleiro, L.; Rejeb, M.N.; Neffati, M.; Costa, M.M.; Figueiredo, A.C.; Barroso, J.G.; Pedro, L.G. Chemical composition, antioxidant and antibacterial activities of the essential oils isolated from Tunisian Thymus capitatus Hoff. et Link. Food Chem. 2007, 105, 146-155. [CrossRef]

41. Bozin, B.; Mimica-Dukic, N.; Simin, N.; Anackov, G. Characterization of the volatile composition of essential oils of some Lamiaceae spices and the antimicrobial and antioxidant activities of the entire oils. J. Agric. Food Chem. 2006, 54, 1822-1828. [CrossRef] [PubMed]

42. Ruberto, G.; Baratta, M.T. Antioxidant activity of selected essential oil components in two lipid model systems. Food Chem. 2000, 69, 167-174. [CrossRef]

43. Teixeira, B.; Marques, A.; Ramos, C.; Neng, N.R.; Nogueira, J.M.F.; Saraiva, J.A.; Nunes, M.L. Chemical composition and antibacterial and antioxidant properties of commercial essential oils. Ind. Crops Prod. 2013, 43, 587-595. [CrossRef]

44. Hagag, A.A.; Amin, S.M.; Emara, M.H.; Abo-Resha, S.E. Gastric mucosal oxidative stress markers in children with Helicobacter pylori infection. Infect. Disord. Drug Targets (Formerly Curr. Drug Targets Infect. Disord.) 2018, 18, 60-67. [CrossRef]

45. Chun, S.S.; Vattem, D.A.; Lin, Y.T.; Shetty, K. Phenolic antioxidants from clonal oregano (Origanum vulgare) with antimicrobial activity against Helicobacter pylori. Process Biochem. 2005, 40, 809-816. [CrossRef]

46. Akyön, Y. Effect of antioxidants on the immune response of Helicobacter pylori. Clin. Microbiol. Infect. 2002, 8, 438-441. [CrossRef]

47. Kang, H.; Kim, H. Astaxanthin and $\beta$-carotene in Helicobacter pylori-induced Gastric Inflammation: A Mini-review on Action Mechanisms. J. Cancer Prev. 2017, 22, 57-61. [CrossRef]

48. Joulain, D.; König, W.A. The Atlas of Spectral Data of Sesquiterpene Hydrocarbons; E.B.-Verlag: Hamburg, Germany, 1998.

49. Adams, R.P. Identification of Essential Oil Components by Gas Chromatography /Mass Spectrometry, ed. 4.1. 2017. Available online: http://essentialoilcomponentsbygcms.com/ (accessed on 15 November 2019).

50. Brand-Williams, W.; Cuvelier, M.; Berset, C. Use of free radical method to evaluate antioxidant activity. LWT-Food Sci. Tech. 1995, 28, 25-30. [CrossRef]

51. Scherer, R.; Godoy, H.T. Antioxidant activity index (AAI) by the 2,2-diphenyl-1-picrylhydrazyl method. Food Chem. 2009, 112, 654-658. [CrossRef]

52. Korona-Glowniak, I.; Cichoz-Lach, H.; Siwiec, R.; Andrzejczuk, S.; Glowniak, A.; Matras, P.; Malm, A. Antibiotic Resistance and Genotypes of Helicobacter pylori Strains in Patients with Gastroduodenal Disease in Southeast Poland. J. Clin. Med. 2019, 8, 1071. [CrossRef]

Sample Availability: Samples of the compounds are available from the authors.

(C) 2020 by the authors. Licensee MDPI, Basel, Switzerland. This article is an open access article distributed under the terms and conditions of the Creative Commons Attribution (CC BY) license (http://creativecommons.org/licenses/by/4.0/). 